DOI https://doi.org/10.36059/978-966-397-242-8-4

Kapn M. A.,

кандидат філологічних наук, доцент, доцент кафедри прикладної лінгвістики Національного університету «Львівська політехніка» м. Львів

\title{
ТЕОРЕТИЧНІ ПЕРЕДУМОВИ ВИВЧЕННЯ ТЕКСТОТВІРНИХ КАТЕГОРІЙ КОГЕЗІЇ І КОГЕРЕНТНОСТІ
}

Анотація. Рефероване дослідження присвячено теоретичним передумовам вивчення текстотвірних категорій когезії та когерентності: когезії $і$ когерентності у взаємодії з іншими категоріями тексту, когезії і когерентності у світлі наукової думки М.А.К. Халлідея і Р. Хасан та їхніх послідовників, інтегральному потенціалу когезії $i$ когерентності у структурно-смисловій організації традиційного та сучасного художнього прозового тексту. У цьому дослідженні схиляємось до лінгвістичного аналізу тексту в межах лінгвістики тексту із залученням граматики тексту та стилістики тексту, оскільки розглядаємо системи засобів двох категорій тексту - когезії і когерентності, зумовлені текстотвірними функціями відмінних мовних одиниць. Когезію визначаємо як формальну, або зовнішню, зв'язність тексту, когерентність - як внутрішню, змістовну зв'язність. У світлі наукової думки провідних вітчизняних і зарубіжних вчених когезія $i$ когерентність $\epsilon$ ключовими компонентами лінгвістичного аналізу тексту в межах лінгвістики тексту і граматики тексту. Засоби когезії й когерентності структурують текст та ранжують смисли в його семантиці. Інтегральний потенціал когезії і когерентності у структурно-смисловій організації сучасного художнього прозового тексту полягає в кореляції з мультимодальністю в межах лінгвістики тексту, граматики тексту і стилістики тексту. Мультимодальність як явище сучасного техногенного суспільства активно ангажується для лінгвістичного аналізу структурносмислової організації художнього прозового тексту сучасності $i$ потребує подальших наукових студій. Мультимодальність описує практику комунікації з точки зору лінгвістичних, візуальних, аудіальних, кінестетичних і просторових модусів/засобів подання інформації для компонування художнього прозового тексту адресантом та покращення сприйняття тексту адресатом за допомогою семіотичних ресурсів. 


\section{Вступ}

Основним принципом формування будь-якого відрізку тексту $є$ виконання ним комунікативної функції, що відображає рух думки автора, 3 урахуванням системних значень мовних одиниць лексичних, що називають поняття і явища реального світу, i граматичних, що виражають зв'язки між ними $[1 ; 2 ; 3 ; 4 ; 5 ; 6 ; 7 ; 8]$. Позиція автора, прагнення до вдалого висловлення думки, до створення тексту, який відповідає художньо-естетичному уявленню, - усе це визначає вибір форми оповіді, вживання лексичних і граматичних одиниць $[9 ; 10 ; 11 ; 12 ; 13 ; 14 ; 15 ; 16 ; 17]$.

Серед категорій тексту когезія і когерентність перебувають у полі зору різних дослідницьких парадигм і набувають інколи відмінних тлумачень $[9 ; 10 ; 1 ; 18 ; 2 ; 13 ; 19 ; 14 ; 3 ; 15 ; 20 ; 21]$. Суть когезії полягає у зчепленні елементів тексту між собою $[22 ; 23 ; 24$; $25 ; 26]$, тим часом як когерентність передбачає внутрішню закінченість, смислову єдність тексту [27; 28; 29; 30; 31; 32; 33]. Утім, попри встановлення ролі окремо взятого висловлення поза текстом і в тексті під час опису його категорій, як справедливо зауважує 3.Я. Тураєва $[3$, с. 80], останні відображають його найзагальніші і найсуттєвіші властивості та являють собою ступені в пізнанні його онтологічних, гносеологічних і структурних ознак.

\section{1. Когезія і когерентність у взаємодії з іншими категоріями тексту}

Текст - це "усвідомлена послідовність вербальних знаків, які володіють властивостями зв'язності та цілісності" [34, с. 127]. Вивчення тексту перебуває в полі зору лінгвістики тексту, граматики тексту і стилістики тексту. Лінгвістика тексту розглядає текст як струкутуру, яка володіє категоріями. Граматика тексту вивчає надфразові єдності, що утворюють надсинтаксичний рівень мови. Стилістика тексту зосереджена на функційно-смислових та композиційно-смислових типах мовлення [11, с. 226]. Чітко розмежувати предмет аналізу в межах кожного розділу лінгвістики складно, оскільки сам предмет є явищем багатоаспектним. Відтак статус кожного розділу лінгвістики визначають неточно, а будь-яке дослідження тексту завжди є комплексом різних підходів" [35, с. 8].

До проблематики лінгвістики тексту зараховують виокремлення текстових категорій та їхніх лінгвальних засобів вираження [9; 36; 10; $1 ; 37 ; 38 ; 39 ; 40 ; 41 ; 2 ; 13 ; 42 ; 43 ; 44 ; 14 ; 45 ; 46 ; 3 ; 15 ; 20 ; 47 ; 48 ; 49 ; 50]$. 
Щодо вивчення граматики тексту увагу акцентують на граматичній структурі в тексті [51; 28; 4; 52]. У межах стилістики тексту аналізують способи організації, зв'язки та співвіднесеність мовних фактів [53; 29; 54; 48; 55].

Текстові категорії ототожнюють із засобами [44] тексту, ознаками [56; 3], граматичними категоріями [1], концептуальними ознаками [57; 58], когнітивними параметрами [59]. О.П. Воробйова кваліфікує категорії тексту як концептуальні ознаки, що відображають найсутєвіші властивості, прототипні ознаки тексту, взаємодія яких забезпечує його специфіку та стійкість як якісно визначеного лінгвосеміотичного, комунікативного та мовномисленнєвого утворення [58]. Фактично, у переліку категорій тексту, що наводяться різними лінгвістичними школами, наявні розбіжності. Залежно від критеріїв, що покладені в основу виявлення текстових категорій, варіюється їхній кількісний склад і змістове наповнення.

I.P.Гальперін виокремлює такі категорії тексту: інформативність, членування, когезію, континуум, автосемантію, ретроспекцію, проспекцію, модальність, інтеграцію та завершиність [1, с. 8-26]. 3.Я. Тураєва розподіляє текстові категорії на структурні (зв'язність, інтеграція, прогресія/стагнація) та змістові (образ автора, художній час і простір, інформативність, причиновонаслідкові зв'язки, підтекст) [3, с. 81]. В.А. Кухаренко акцентує увагу на категоріях членування, зв'язності, проспекції, ретроспекції, антропоцентричності, локально-темпоральної співвіднесеності, концептуальності, інформативності, системності, цілісності та модальності [2, с. 70-79].

А.П. Загнітко до текстових категорій зараховує: категорію події, часу, простору, оцінки та інформативності [60, с. 489]. 0.0. Селіванова розрізняє текстово-дискурсні категорії цілісності, дискретності, інформативності, зв'язності, континууму, референційності, антропоцентричності, інтерактивності, інтерсеміотичності [14, с. 275]. А.Ф. Папіна розглядає п'ять глобальних категорій тексту: перша охоплює учасників комунікативного акту, учасників подій, ситуацій; друга - події, процеси, факти; третя - часу; четверта - художній простір; п'ята оцінки [44, с. 91-326]. Н.С. Валгіна наголошує на категорії цілісності, зв'язності, інформативності, модальності та категоріях часу i 
простору [10]. В.О. Лукін виокремлює категорію зв'язності та цілісності [13, с. 22-58].

Л.Г. Бабенко ідентифікує такі категорії тексту: цілісність, зв'язність, завершеність, абсолютна антропоцентричність, соціологічність, діалогічність, "розгорнутість" і послідовність, статичність і динамічність, напруженість, естетичність, образність, інтерпретованість [9, с. 40-45]. На думку дослідниці, когезія і когерентність групують співвідносні категорії. Когерентність тексту забезпечується категоріями інформативності, інтегративності, завершеності, хронотопу (час та простір у тексті), образу автора та персонажа, модальності, емотивності, експресивності $[9$, с. 42].

На думку O.І. Москальської, взаємозв'язок складників у граматиці тексту виявляється у смисловій, комунікативній та структурній цілісності, які корелюють між собою як зміст, функція і форма [28, с. 17-30]. О.М. Мороховський та О.П. Воробйова основними категоріями в дослідженні стилістики тексту вважають інтегративність, дискретність, персональність/імперсональність та настанову на читача [29, с. 207-226].

В.Л. Цаммунер виокремив стратегії говоріння в тексті: стратегії встановлення фону для обговорюваної проблеми, стратегії введення, напрацювання теми, фокусування, відвернення уваги [61]. Р. Фаулер критерії називав аспектами структури тексту й виділяв: когезію, динамічність та локалізованість [22, , p. 24]. Р. де Богранд й В.У.Дресслер описали сім критеріїв текстуальності, до яких віднесли критерії когезії, когерентності, інтенційності, прийнятності, інформативності, ситуативності й інтертекстуальності [20, p. 3-11].

Синонімічний ряд когезії [20]охоплює зв'язність [9; 10; 2; 13; 14; 3], зовнішню злитість [18]; тоді як когерентності [20] інтеграцію [1; 3], інтегративність [29], цілісність [9; 10; 2; 13; 28; 14], завершеність [1; 2], внутрішню злитість [18].

Оскільки змістове наповнення термінів “когезія" і “когерентність" здійснювали впродовж тривалого часу представники різних вітчизняних та зарубіжних лінгвістичних шкіл за різних лінгвістичних парадигм, то важливо розкрити їхнє значення, яке відображає сучасний стан розвитку лінгвістики тексту.

Когезія - “структурно-граматичний різновид зв'язності тексту, показниками якого є формальні засоби зв'язку слів, речень, зокрема 
узгодженість морфологічних категорій слів, синтаксичні відношення сурядності й підрядності, поверхова організація синтаксичних структур, повтори, анафоричні зв'язки, дейксис, сполучники, порядок слів. Когезія протиставлена когерентності змістовому різновиду зв'язності. Термін запозичений із фізики й уведений в обіг лінгвістики тексту В.У. Дресслером, Р. де Бограндом, М.А.К. Халлідеєм" [62, с. 230]. Тобто це - типи зв'язків, що "забезпечують континуум, логічну послідовність, (темпоральну і/або просторову) взаємозалежність окремих фактів, дій” [1, с. 74]. Це “зв'язок елементів тексту, коли інтерпретація одних елементів тексту залежить від інших" [63, с. 37].

Когерентність - “змістовий, семантичний різновид зв'язності, показниками якого $є$ семантичне узгодження лексичних одиниць, тематично однорідні ряди слів, повтори, синоніми, антоніми, пароніми, гіпероніми, гіпоніми..., семантико-стилістичні фігури..." $[62$, с. 230]. Це "властивість тексту, яка полягає у тому, що він (як макро-, так і мікро-) становить єдине висловлення і має цілісний характер. Розгляд тексту на рівні когерентності означає вивчення його змістових потенцій” [64, с. 31]. Це також “зв'язність, що привноситься чимось зовнішнім щодо тексту, перш за все знаннями його адресата" [63, с. 37].

Отже, із врахуванням сказаного когезію визначаємо як формальну, або зовнішню, зв'язність тексту, когерентність - як внутрішню, змістовну зв'язність. I в такій інтерпретації остання використовується аналогічно тому, що І.Р. Гальперін називає інтеграцією [1, с. 124-135], а Л.Г. Бабенко інтегративністю $[9$, c. 41-42] у лінгвістичному аналізі тексту.

\section{2. Когезія і когерентність у світлі наукової думки}

\section{М.А.К. Халлідея і Р. Хасан та їхніх послідовників}

У праці “Cohesion in English" (1976) М.А.К. Халлідей та Р. Хасан визначають когезію як "набір значущих відносин, спільний для всіх текстів, який відрізняє текст від "не-тексту" і який слугує засобом виявлення взаємозалежності змісту окремих відрізків. Когезія не виявляє, що повідомляє текст; вона виявляє, як текст організовано в семантичне ціле (semantic edifice)" [52, p. 26]. Пов'язуючи текст із структурою та дискурсом ("дискурс народжується у тексті" [52, p. 327]), учені визначили когезію через граматичну структуру 
та мовну систему. Вони запропонували класифікацію засобів когезії, яку адаптовано у вигляді схеми, зображеної на рис. 1.1.

М.А.К. Халлідей і Р. Хасан виокремлюють п'ять видів когезійних зв'язків: референцію (ендоферичну: особову, вказівну, порівняльну), субституцію (номінальну, дієслівну, клаузальну: повідомлення, умовність, модальність), еліпсис (номінальний: дейктичний, нумеративний, епітет, класифікатор; дієслівний; клаузальний), кон'юнкцію (адитивну, адверсативну, каузальну, темпоральну) та лексичну когезію (лексичний повтор, словосполучення).

Види когезї - семантичні, лексико-граматичні та структурні зв'язки, що грунтуються на понятті “пресупозиції” (presupposition): один елемент передбачає інший, який перебуває в тексті або в контексті ситуації та $\epsilon$ важливим для інтерпретації тексту. Пресупозиція здійснюється на семантичному, лексикограматичному та граматичному рівнях [52, р. 1-30].

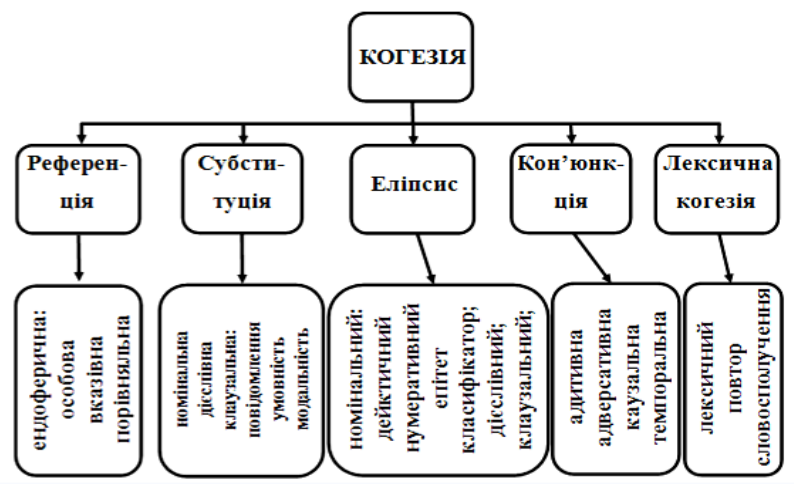

\section{Рис. 1.1. Класифікація засобів когезії у структурі тексту}

До слова, українська дослідниця 0.0. Селіванова наголошує, що пресупозиція $є$ "імпліцитним складником змісту висловлення або тексту, який $\epsilon$ істинним і несуперечливим, передує їхньому вербальному плану та сприяє їх успішному сприйняттю й розумінню" [62, с. 589].

На думку В.У.Дресслера, когезія як результат напрацювання представників Сіднейської лінгвістичної школи в межах системної функційної лінгвістики М.А.К.Халлідея та Р.Хасан є суттєвим 
внеском у вивченні міжреченнєвої когерентності та її інтеракції зі структурою речення [52, p. 380].

Свого часу у праці "Introduction to Text Linguistics" (1981) P.-А. де Богранд і В.У.Дресслер представили концепцію семи критеріїв текстуальності (сукупності властивостей текстукомунікату), зокрема виокремлюючи критерії когезї та когерентності як текстотвірні [20, р. 3-11].

Критерій когезії впливає на спосіб утворення поверхневої структури тексту - спосіб співвіднесеності його компонентів. Компоненти поверхневої структури тексту з'єднуються засобами граматичних форм і граматичних зв'язків. Когезія грунтується на граматичній залежності компонентів [20, р. 41-67]. Адресант та адресат намагаються встановити змістові взаємозв'язки між окремими компонентами тексту, навіть якщо зв'язок не марковано когезійними засобами. В основі тексту лежить комбінація властивостей - складова світу тексту (Textwelt). “Світ тексту" визначається “смисловою безперервністю” тексту. На думку, P.-А.де Богранда та В.У.Дресслера, безперервність смислу $\epsilon$ основою когерентності тексту [20, р. 71].

Когерентність тексту грунтується на смисловій безперервності “світу тексту" та впливає на спосіб утворення глибинної структури тексту. Смисл тексту полягає в актуалізації текстових взаємозв'язків. “Світ тексту” - це сукупність смислових відносин у тексті. Цей світ складається з концептів та зв'язків між ними. Концепти - це одиниці знання, утворені на основі сприйняття та досвіду, які не завжди об’єктивно відображають реальний світ. Якщо існує розбіжність між комбінацією концептів у “світі тексту" і знаннями про світ адресата, тоді адресат не може виявити безперервність смислу, і такий текст стає для нього безсмисловим [20, р. 71-109].

Для опису когерентності ключовим поняттям $\epsilon$ когерентні зв'язки, репрезентовані Дж.Р. Гоббсом 1979 року, послідовником М.А.К. Халлідея та Р. Хасан. Когерентні зв’язки описують “у який спосіб частини дискурсу рекурсивно компонуються, щоб утворити об'ємніші сегменти та повноцінну структуру" [30, p. 67-90]. Когерентні зв'язки встановлюють семантичні або прагматичні зв'язки між одиницями пропозицій (смислових струкутур речення) або іллокуцій (цільова спрямованість висловлення): найменшими одиницями $є$ речення або самостійні фрагменти, найбільшою одиницею - ціліснооформлений дискурс. Розмежування між 
семантичними та прагматичними зв'язками когерентності запропонував Т. ван Дейк, констатуючи, що семантичні зв'язки зберігаються між денотативними фактами, тоді як прагматичні зв'язки - між мовленнєвими актами [65, р. 447-456].

Функційна класифікація когерентних зв'язків грунтується на засадах системної функційної лінгвістики М.А.К. Халлідея та полягає в розмежуванні досвідної (experiential/ideational), міжособистісної (interpersonal), текстової (textual) метафункцій мови [16; 66]. Когерентну структуру дискурсу репрезентують ієрархічною структурою в теорії комунікації, що охоплює семантичні (semantic/ideational), риторичні (rhetorical/interpersonal), текстові (textual/ sequential) когерентні зв'язки [67, p. 243-281].

Ядерні когерентні зв'язки - це послідовний набір механізмів для когнітивного опрацювання розуміння тексту. Т.Сандерс запропонував чотири фундаментальні категорії ядерного когерентного зв'язку, які класифіковано в системній мережі [31, p. 1-35] (див. рис. 1.2).

Каузальний зв'язок за рис. 1.2 спостерігаємо між змістом двох повідомлень. Базова/небазова відмінність стосується порядку, в якому причина і спричинене присутні. Опозиція позитивний $\leftrightarrow$ негативний рівень у цій ієрархії вказує на конкрентний когерентний зв'язок текстових елементів, а семантичний $\leftrightarrow$ прагматичний рівень в ієрархії ядерних когерентних зв'язків свідчить про зв'язок між семантичним контентом повідомлення і самими повідомленнями.

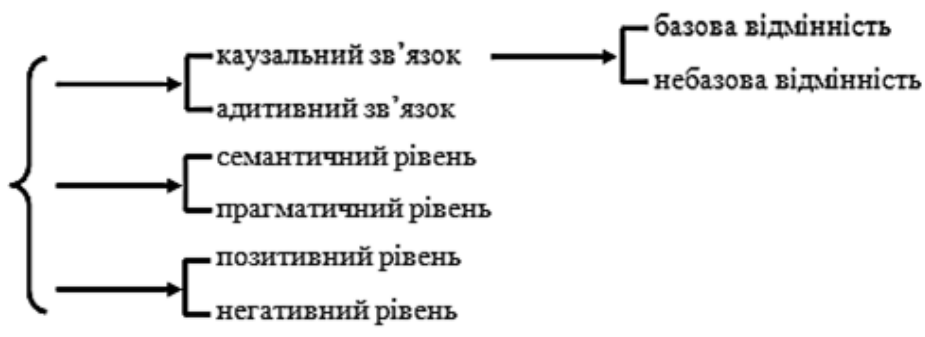

\section{Рис. 1.2. Ієрархія ядерних когерентних зв'язків за Т. Сандерсом}

Отже, у світлі наукової думки М.А.К. Халлідея, Р. Хасан та їхніх послідовників когезія й когерентність як текстотвірні категорії 
стають ключовими компонентами лінгвістичного аналізу тексту. Засоби когезії й когерентності структурують текст та ранжують смисли в його семантиці.

\section{3. Інтегральний потенціал когезії і когерентності у структурно-смисловій організації традиційного}

\section{художнього прозового тексту}

Традиційний художній прозовий текст являє собою єдність, яка дробиться на елементи, але не являється результатом їх зчіплювання [68]. Аби збагнути текст, адресат встановлює зв'язок між одиницями тексту, проте він не сприймає тексту як цілого: розуміючи когерентність, можна осягнути когезію, проте зворотний процес $\epsilon$ безрезультатним. На думку В.О.Лукіна, індуктивний аналіз тексту “від когезії до когерентності" передбачає рух від часткового до цілого. Превалювання цілого над його частинами свідчить про безрезультативність такого аналізу. Дедуктивний аналіз тексту "від когерентності до когезії" передбачає рух від цілого до часткового. Він зумовлює можливість адресата зрозуміти текст у його цілісності, не беручи до уваги нерозуміння ним окремих слів чи словосполучень у тексті, яке нівелюється зверненням до когезії. Конструктивна роль когерентності в аналізі тексту полягає в тому, що вона сприяє встановленню латентних зв'язків між частинами тексту. Адресат сприймає частини тексту, об'єднаних когерентністю внаслідок рефлексії над текстом [13, с. 42-57].

Н.С. Валгіна ідентифікує текст як "інформаційну та структурну єдність, функційно завершене мовленнєве ціле". Когезія та когерентність - це конструктивні ознаки тексту, які віддзеркалюють його змістовну й структурну сутність. Когезія тексту виявляється крізь зовнішні структурні показники, через формальну залежність компонентів тексту. Когерентність тексту лежить у площині тематичного, концептуального і модального зв'язку. Поняття когерентності тексту - це його змістовна і комунікативна організація на противагу когезії - форма і структурна організація тексту [10, с. 43].

Текст володіє нероздільними ознаками структурної когезії та змістовної когерентності, які нашаровуються. Наявність однієї ознаки не свідчить про доцільно створений текст. У плані вираження текст може бути когезійним (використання засобів 
синтаксичного зв'язку, дотримання тема-рематичної послідовності), проте у плані змісту такий текст може виявитись абсурдним. Для оформлення тексту в осмислену структурну єдність потрібні його текстотвірні категорії - когезія та когерентність, які, безумовно, вміщують його комунікативну настанову [10, с. 48-52].

В.Б. Касевич окреслює проблематику лінгвістики тексту: об’єктом їі вивчення $\epsilon$ опис і моделювання текстів, так само як когезія i когерентність $[69$, с. 50]. На думку К.А.Філіпова, когезія та когерентність об'єднують текстові елементи в єдине ціле, торкаючись організації мовленнєвого твору. Якщо когерентність - це внутрішня завершеність, смислова єдність тексту, то когезія полягає у зчепленні безпосередніх і дистантних елементів тексту [15, с. 134-137].

Важливо наголосити на тому, що когезія реалізується в синтагматичному розрізі, а когерентність являє собою парадигматичний процес: когезія лінійна, а когерентність вертикальна [1, с. 125]. Словом, когезія та когерентність - це системні властивості тексту. Завдяки цим властивостям текст належить до системи мови. Власне Л.М. Мурзін і А.С.Штерн виводять поняття когезії й когерентності з кореляції синтагматики і парадигматики, наголошуючи на тому, що “когезія обумовлена лінійністю тексту, що відповідає природі одиниці мови; когерентність - введенням у парадигматичні відносини" [19, с. 11].

Якщо зобразити графічно ці текстотвірні категорії, то когерентність - це вертикаль схеми, а когезія - горизонталь (див. рис. 1.3). Вісі координат взаємодіють. Когерентність зовні матеріалізується в когезію. Когезія, зумовлена когерентністю, створює умови для їі виникнення [9, с. 42]. “Когерентність - це характеристика результату сприйняття внутрішньо зв'язного тексту, а когезія - це засіб отримання цієї характеристики" [70, с. 27].

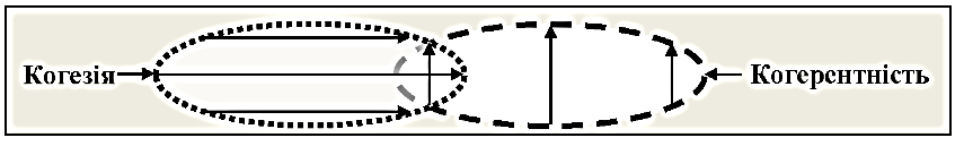

\section{Рис. 1.3. Інтегральний потенціал когезії і когерентності у текстопросторі}

У граматиці тексту парадигматичні зв'язки розташовані в одній семантико-функційній площині граматичної системи між 
граматичними формами [51, с. 13]. Синтагматична система мови існує як набір множин типів взаємозв'язків між граматичними компонентами мовлення [51, с. 20].

Адресат виявляє властивості тексту, які повторюються. Адресант повторює найважливіше, починаючи від явищ навколишньої дійсності і завершуючи мовними засобами їхнього втілення [2, с. 85]. Текст являє собою продукт комунікативної ситуації, яка віддзеркалена в організації складників його мовних засобів [2, с. 84].

Існує відмінність між вертикальним контекстом та фоновими знаннями. Фонові знання - це сукупність фактів, якими володіє адресант та адресат; вертикальний контекст - це належність одиниці тексту. Одиниця тексту, репрезентована різноманітністю горизонтальних контекстів, має своєрідний вертикальний контекст безпосередньо недосяжний для адресата [12, с. 7].

Форма тексту як лінійна схема містить горизонтальний та вертикальний складники. Відмінність стану структури спричинює горизонтальну динаміку в структурі цілого. Смисл цілого виникає поступово та визначається завершенням тексту. Компоненти форми об'єднані у фрагменти. Форма цілого завершена в часі текст має початок і кінець. Гармонія цілого залежить від статичної рівноваги горизонтальної і вертикальної динаміки структури у сприйнятті адресатом. Внаслідок взаємодії горизонтальної й вертикальної динаміки створюється індивідуальна форма цілого [42, c. 214-215].

Міркування дослідників у проблематиці об'єднавчого потенціалу вербальних та невербальних засобів когезії й когерентності у смисловій організації мультимодального художнього прозового тексту є розбіжними $[71 ; 72 ; 73 ; 74 ; 75 ; 76$; 77; 78; 79]. Інтеграцію між когезією, когерентністю та мультимодальністю прозового тексту можна зобразити графічно (див. рис. 1.4). 


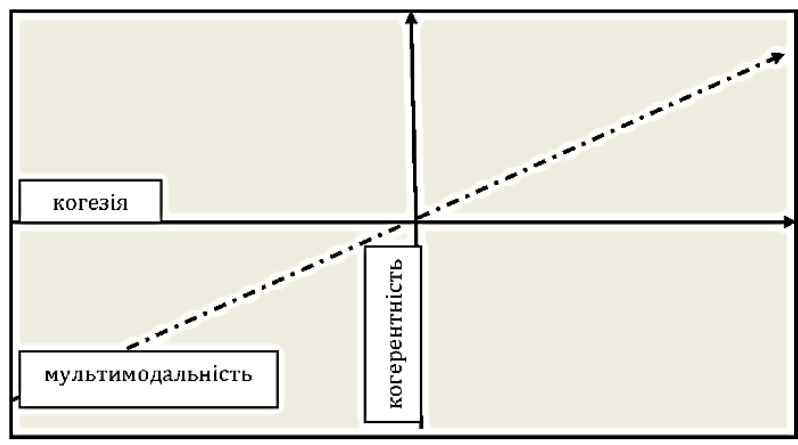

Рис. 1.4. Взаємодія когезії, когерентності та мультимодальності

Відповідно, когезія художнього прозового тексту $\epsilon$ горизонтальною категорією логічного плану, що дотримується правил граматики, лексики та семан- тики на рівні синтагматики. Когерентність $\epsilon$ вертикальною категорією, яка забезпечує смисловий зв'язок між надфразовими єдностями для виявлення гіпертеми і мікротем на рівні парадигматики.

Водночас мультимодальність $€$ епідигматичною категорією, яка контамінує вербальний та невербальний складники когезії й когерентності, поглинаючи їхні текстотвірні ознаки. Іконічний компонент функціонує в мові, так само як вербальний компонент $\epsilon$ складовою частиною іконічного [80, p. 10]. Мультимодальність являє собою ланку, яка перебуває в пошуку зв'язку між відмінними семіотичними засобами - вербальним та іконічним [77, p. 4]. Сукупність семіотичних принципів мультимодальності функціонує між відмінними засобами когезії й когерентності [81, p. 2]. Вербальний складник є лінійним засобом, який інтегрує знаки художнього тексту в ціле на противагу іконічному складнику, що грунтується на перцепції адресата [80, р. 17].

Отже, об'єднавчий потенціал когезії та когерентності не виводиться із властивостей окремих елементів чи з відносин між ними і не дорівнює сумі їхніх властивостей, проте полягає в кореляції 3 мультимодальністю. Мультимодальність як явище сучасного техногенного суспільства активно ангажується для лінгвістичного аналізу структурно-смислової організації 
художнього прозового тексту сучасності і потребує подальших наукових студій.

\section{Висновки}

Теоретичні передумови вивчення текстотвірних категорій когезії і когерентності грунтуються на лінгвістичному аналізі тексту в межах триєдності його лінгвістики, граматики і стилістики, які корелюють у просторі сучасних мовознавчих студій. У цьому дослідженні схиляємось до лінгвістичного аналізу тексту в межах лінгвістики тексту із залученням граматики тексту та стилістики тексту, оскільки розглядаємо системи засобів двох категорій тексту - когезії і когерентності, зумовлені текстотвірними функціями відмінних мовних одиниць [82; 83; 84; 85].

У сучасних мовознавчих студіях напрямки лінгвістики тексту об'єднані постулатами зв'язності (когезії) тексту та націлені на його цілісність (когерентність). Когезія і когерентність як текстотвірні категорії тісно взаємодіють з іншими категоріями тексту. У світлі наукової думки провідних вітчизняних і зарубіжних вчених когезія і когерентність $\epsilon$ ключовими компонентами лінгвістичного аналізу тексту в межах лінгвістики тексту і граматики тексту [86]. Засоби когезії ранжують смисли в семантиці тексту. Засоби когерентності структурують текст.

Інтегральний потенціал когезії і когерентності у структурносмисловій організації сучасного художнього прозового тексту полягає в кореляції з мультимодальністю в межах лінгвістики тексту, граматики тексту і стилістики тексту [87; 88; 89]. Мультимодальність описує практику комунікації 3 точки зору лінгвістичних, візуальних, аудіальних, кінестетичних і просторових модусів/засобів подання інформації для компонування художнього прозового тексту адресантом та покращення сприйняття тексту адресатом за допомогою семіотичних ресурсів.

\section{Список використаних джерел:}

1. Гальперин И. Р. Текст как объект лингвистического исследования. Москва : Наука, 1981.139 с.

2. Кухаренко В. А. Інтерпретація тексту : [підруч. для студ. старших курсів філол. спец.]. Вінниця : Нова книга, 1988. 272 с.

3. Тураева 3. Я. Лингвистика текста. (Текст: структура и семантика). Москва : Просвещение, 1986. 127 с. 
4. Brinton L. J., Traugott E. C. Lexicalization and Grammaticalization in Language Change. Research Serveys in Linguistics. Cambridge : Cambridge University Press, 2005. 194 p.

5. Gleason H. A. Linguistics and English Grammar. Canada : Holt Rinehart and Winston, $1965.519 \mathrm{p}$.

6. Huddleston R. Introduction to the Grammar of English. Cambridge : Cambridge University Press, 1984. 483 p.

7. Munat J. Lexical Creativity, Texts and Contexts. Studies in Functional and Structual Lingustics / ed. by Judith Munat. Amsterdam ; Philadelphia : John Benjamins Publishing Company, 2007. Vol. 58. 229 p.

8. Chalker S., Weiner E. Oxford Dictionary of English Grammar. Oxford : Oxford University Press, 1998. 448 p.

9. Бабенко Л. Г., Казарин Ю. В. Лингвистический анализ художественного текста. Теория и практика. 4-е изд., испр. Москва : Флинта : Наука, 2005. 496 с.

10. Валгина Н. С. Теория текста. - Москва : Логос, 2003. 280 с.

11. Ворожбитова А. А. Теория текста: антропоцентрическое направление. Москва : Высш. шк., 2005. 367 с.

12. Гюббенет И. В. Основы филологической интерпретации литературно-художественного текста. Москва : Изд-во МГУ, 1991. 205 с.

13. Лукин В. А. Художественный текст: основы лингвистической теории и элементы анализа. Москва : Ось-89, 1999. 192 с.

14. Селиванова Е. А. Основы лингвистической теории текста и коммуникации : монограф. учеб. пособие. Киев : Фитосоциоцентр, 2002. $336 \mathrm{c}$.

15. Филиппов К. А. Лингвистика текста: курс лекций. СанктПетербург : Изд-во С.-Петерб. ун-та, 2003. 336 с.

16. Halliday M. A. K. An Introduction to Functional Grammar. Second edition. Foreign Language Teaching and Research Press : Edward Arnold (Publishers) Ltd., 1994. 497 p.

17. Николаева Т. М. Краткий словарь терминов лингвистики текста / сост. Татьяна Михайловна Николаева // Новое в зарубежной лингвистике: лингвистика текста. Москва, 1978. Вып. 8. 479 с.

18. Кожевникова К. Об аспектах связности в тексте как целом. Синтаксис текста. Москва : Наука, 1979. С. 49-67.

19. Мурзин Л. Н., Штерн А. С. Текст и его восприятие. Свердловск : Изд-во Урал. ун-та, 1991. 171 с.

20. Beaugrande R.-A. De, Dressler W. U. Introduction to Text Linguistics. London ; New York : Longman, 1981. 270 p. 
21. Sanders T., Maat H. P. Cohesion and Coherence: Linguistic Approaches. London : Elsevier, 2006. P. 1-201. (Encyclopedia of Language and Linguistics Series; second edition).

22. Fowler R. Literature as Social Discourse. London : Batsford, 1981. $258 \mathrm{p}$.

23. Gutwinski W. Cohesion in Literary Texts. Netherlands : De Gruyter, 1976. $176 \mathrm{p}$.

24. Halliday M. A. K., Hasan R. Cohesion in English. London : Longman, 1976. $392 \mathrm{p}$.

25. Markels R. B. A New Perspective on Cohesion in Expository Paragraphs. Studies in Writing and Rhetoric. USA : Conference on College Composition and Communication, 1984. 106 p.

26. Masterman M. Language, Cohesion, and Form / ed. by Tarick Wilks. New York : Cambridge University Press, 2005. 313 p.

27. Гиндин С. И. Внутренняя организация текста. Москва, 1972. 325 с.

28. Москальская О. И. Грамматика текста. Москва : Высш. шк., 1981. $183 \mathrm{c}$.

29. Мороховский А. Н., Воробьева О. П., Лихошерст Н. И., Тимошенко 3. В. Стилистика английского языка. Киев : Вища шк., 1984. 248 с.

30. Hobbs J. R. Coherence and Coreference. Cognitive Science 3. 1979. P. 67-90.

31. Sanders T., Spooren W., Noordman L. Toward a Taxonomy of Coherence Relations. Discourse Processes. 1992. № 15 (1). P. 1-35.

32. Sanders T. Spooren W., Noordman L. Coherence Relations in a Cognitive Theory of Discourse Representation. Cognitive Linguistics. 1993. № 4 (2). P. 93-133.

33. Gruber H., Redeker G. The Pragmatics of Discourse Coherence: Theories and Applications / ed. by Helmut Gruber, Gisela Redeker. Amsterdam ; Philadelphia : John Benjamins, 2014. 295 p. (Pragmatics and Beyond New Series).

34. Васильева Н. В., Виноградов Н. В., Шахнарович А. М. Краткий словарь лингвистических терминов. Москва : Рус. яз., 1995. 176 с.

35. Исаева Л. А. Художественный текст: скрытые смыслы и способы их представления. Краснодар, 1996. 310 с.

36. Безугла Л. Р. Дискурсивные и текстовые категории: к разграничению понятий. Методи аналізу текста : зб. наук. пр. Чернівці : Рута, 2009. С. 40-52.

37. Головкина С. Х., Смольников С. Н. Лингвистический анализ текста. Вологда : Изд. центр ВИРО, 2006. 124 с. 
38. Гришаева Л. И. Теория языка; Воронеж. гос. ун-т. Воронеж : ВГУ, 2011. $151 \mathrm{c}$.

39. Жинкин Н. И. Язык - речь - творчество : избранные труды ; [сост., науч. ред., текстолог. прим., биограф. очерк. С.И. Гиндина ; подгот. текста С.И. Гиндина и М.В. Прокопович]. Москва : Лабиринт, 1998. 368 с.

40. Касавин И. Т. Текст. Дискурс. Контекст. Введение в социальную эпистемологию языка. Москва : Канон+, 2008. 437 с.

41. Кубрякова Е. С. Язык и знание: на пути получения знаний о языке: части речи с когнитивной точки зрения: роль языка в познании мира ; [Ин-т языкозн. РАН]. Москва : Языки славян. к-ры, 2004. 560 с.

42. Москальчук Г. Г. Структура текста как синергетический процесс. Москва : Едиториал УРСС, 2003. 296 с.

43. Новиков Л. А. Художественный текст и его анализ. [Изд. 2, испр.]. Москва : Едиториал УРСС, 2003. 304 с.

44. Папина А. Ф. Текст: его единицы и глобальные категории. Москва : Едиториал УРСС, 2002. 368 с.

45. Селіванова 0. О. Сучасна лінгвістика: напрями та проблеми : підруч. Полтава : Довкілля-К, 2008. 712 с.

46. Селиванова Е. А. Энигматический дискурс: вербализация и когниция : моногр. Черкассы : Изд-во Ю. Чабаненко, 2014. 224 с.

47. Berrio A. G. A Theory of the Literary Text // Translated from Spanish into English by Kenneth Horn. Berlin ; New York : Walter de Gruyter, $1992.544 \mathrm{p}$.

48. Ehrlich S. Point of View: A Linguistic Analysis of Literary Style. Routledge Revivals. London ; New York : Routledge, 2014. 146 p.

49. Ахманова О. С. Словарь лингвистических терминов. Москва : Просвещение, 1969.607 с.

50. Голянич М. І. Лінгвістичний аналіз тексту : словник термінів / [Марія Іванівна Голянич, Наталія Ярославівна Іванишин, Руслана Любомирівна Ріжко, Роксолана Іванівна Стефурак] ; за ред. М. І. Голянич. Івано-Франківськ : Сімик, 2012. 392 с.

51. Адмони В. Г. Основы теории грамматики. - Москва ; Ленинград : "Наука", 1964. 107 с.

52. Halliday M. A. K., Hasan R. Cohesion in English. London ; New York : Routledge, Taylor and Francis Group, 2013.374 p.

53. Кухаренко В. А. Практикум з стилістики англійської мови : підруч. Вінниця : Нова книга, 2000. 160 с. 
54. Арнольд И. В., Фомичева Ж. Е., Андреев В. Н., Родионова И. В. Основы стилистики текста. 2-е изд. Тула : Изд-во Тул. гос. пед. ун-та им. Л. Н. Толстого, 2012.306 с.

55. Niazi N., Gautam R. How to Study Literature: Stylistic and Pragmatic Approaches. New Delhi : PHI Learning Private Ltd, 2010. 305 p.

56. Мороховский А. Н. К проблеме текста и его категорий. Текст и его категориальные признаки : сб. науч. тр. КГПИИЯ. Киев, 1989. С. 3-8.

57. Воробьева О. П. Лингвистические аспекты адресованности художественного текста : дис. ... д-ра филол. наук : 10.02.19. Москва, 1993. 382 с.

58. Воробьева О. П. Текстовые категории и фактор адресата. Киев, 1993. $200 \mathrm{c}$.

59. Щирова И. А., Гончарова Е. А. Многомерность текста: понимание и интерпретация. Санкт-Петербург : Книжный дом, 2007. 472 с.

60. Загнітко А. П. Теоретична граматика української мови: синтаксис : моногр. Донецьк : ДонНУ, 2001. 662 с.

61. Zammuner V. L. Speech Production. Strategies in Discourse Planning: a theoratical and empirical enquiry. - Hamburg : H. Buske Verlag, 1981.310 s.

62. Селіванова О. О. Лінгвістична енциклопедія. Полтава : Довкілля, $2010.844 \mathrm{c}$.

63. Загнітко А. П. Сучасні лінгвістичні теорії : моногр. 2-ге вид., випр. і доп. Донецьк : ДонНУ, 2007. 219 с.

64. Демський М. Т., Краснова Л. В. Словник метамови інтерпретатора художнього тексту / за ред. М. І. Дубини. Київ : ІСДО, $1994.60 \mathrm{c.}$

65. Van Dijk T. A. Pragmatic Connectives. Journal of Pragmatics. 1979. № 3 (5). P. 447-456.

66. Redeker G. Coherence and Structure in Text and Discourse. In Abduction, Belief and Context in Dialogue: Studies in Computational Pragmatics / ed. by Harry Bunt, William Black. Amsterdam : John Benjamins, 2000. P. 233-261.

67. Mann W. C., Thompson S. A. Rhetorical Structure Theory: Towards a Functional Theory of Text Organization. Text 8. 1988. P. 243-281.

68. Греймас А. Ж. Структурная семантика: поиск метода / пер. с фр. Л. Зиминой. Москва : Акад. проэкт, 2004. 368 с.

69. Касевич В. Б. Семантика. Синтаксис. Морфология. Москва, 1988. 309 c.

70. Новиков А. И. Семантика текста и ее формализация. Москва : Наука, 1983. 215 с. 
71. Baldry A., Thibault P. J. Multimodal Transcription and Text Analysis: A Multimedia Toolkit and Coursebook. Equinox Textbooks and Surveys in Linguistics. London ; Oakville : Equinox, 2006. 270 p.

72. Bateman J. Text and Image: A Critical Introduction to the Visual / Verbal Divide. London; New York : Routledge, 2014. 292 p.

73. Kress G. R., van Leeuwen T. Reading Images. The Grammar of Visual Design. Great Britain : Edmundsbury Press Limited, 1996. 288 p.

74. Unsworth L. Multimodal Semiotics: Functional Analysis in Contexts of Education / ed. by Len Unsworth. Bloomsbury Academic, 2011. 270 p.

75. O'Halloran K. L., Smith B. A. Multimodal Studies: Exploring Issues and Domains / ed. by Kay L. O'Halloran, Bradley A. Smith. London ; New York : Routledge, 2011.267 p.

76. Bowcher W. L. Multimodal Texts from Around the World: Cultural and Linguistic Insights / ed. by Wendy L. Bowcher. Palgrave Macmillan, 2012. $330 \mathrm{p}$.

77. Page R. New Perspectives on Narrative and Multimodality / ed. by Ruth Page. London ; New York : Routledge, 2010. 229 p. (Series in Routledge Studies in Multimodality; first edition).

78. Ventola E., Charles C., Kaltenbacher M. Perspectives on Multimodality / ed. by Eija Ventola, Cassily Charles, Martin Kaltenbacher // Document Design Companion Series. Amsterdam ; Philadelphia : John Benjamins Publishing, 2004. 249 p.

79. Royce T. D. Multimodal Communicative Competence in Second Language Contexts. New Directions in the Analysis of Multimodal Discourse. New York : Lawrence Erlbaum \& Assoc., 2007. P. 361-390.

80. Stöckl H. In-between language and image in printed media. In Eija Ventola Perspectives on Multimodality. Amsterdam ; Philadelphia : John Benjamins, 2004. P. 9-30.

81. Kress G. R., van Leeuwen T. Multimodal Discourse: The modes and media of contemporary communication. Bloomsbury Academic, 2001.142 p.

82. Карп М. А. Когезія у сучасних британських художніх текстах. П’ятий міжнародний науковий форум. Сучасна англістика $i$ романістика: перший рубіж нового тисячоліття : тези доп. / за ред. В. О. Самохіної. Харків : Харківс. нац. ун-т ім. В.Н. Каразіна, 2013. С. 71-73.

83. Карп М. А. Когерентність у сучасних британських художніх текстах. Актуальні проблеми германо-романської філології та освітній соціокультурний процес : матер. Міжнар. наук.-практ. конф. (Тернопіль, 4-5 жовтня 2013 р.) / за ред. Б. І. Гінки, І. П. Задорожної, І. Я. Яцюка. Тернопіль : Тернопільс. нац. педаг. ун-т ім. В. Гнатюка, 2013. С. 97-98. 
84. Karp M. Multimodal means of cohesion and coherence in British literary texts: semiotic and synergetic interpretation. Proceedings of Doctoral colloquium Fictional Discourses: in Search of Textual Environment. Chernivtsi : RODOVID, 2013. P. 19-20.

85. Карп М. А. Когезія і когерентність у взаємодії з іншими категоріями тексту. Людина. Комп'ютер. Комунікація: Збірник наукових праць / за ред. проф. О. П. Левченко. Видавництво Львівської Політехніки, 2019. 1 електрон. опт. диск (DVD-ROM). C. 90-93.

86. Karp M. Cohesion in English texts. European Applied Sciences: Philology and Linguistics. Stuttgart : ORT Publishing, September, 2013. № 9-2. P. 10-11.

87. Бехта I. А., Карп М. А. Мультимодальні засоби когезії та когерентності у сучасних літературних казках: теоретико-методологічна інтерпретація. Науковий вісник Міжнародного гуманітарного університету. Сер. “Філологія”. Одеса, 2014. № 12/13. С. 87-90.

88. Карп М. А. Інтегральний потенціал когезії та когерентності у структурносмисловій організації британського художнього тексту. Науковий вісник Чернівецького університету : зб. наук. пр. Чернівці : Вид. дім “РОДОВІД”, 2014. Вип. 708/709 : Германська філологія. С. 86-89.

89. Karp M. Multimodal text analysis regarding cohesion and coherence. Proceedings of the 1st International Sciences Conference Science and Education in Australia, America and Eurasia: Fundamental and Applied Science. International Agency for the Development of Culture, Education and Science. Australia, Melbourne, 2014. (Australia, Melbourne, 25 June 2014). Vol. II. Melbourne IADCES Press. Melbourne, 2014. P. 361-363. 